\title{
HEMODYNAMIC CHANGES AFTER EPINEPHRINE (1:200000) INFILTRATION WITH OR WITHOUT LIGNOCAINE IN ENT SURGERIES
}

Shanaz Geelani ${ }^{1}$, Khursheed Ahmad Bhat ${ }^{2}$, Mushtaq Ahmad Rather ${ }^{3}$, Farhana Bashir ${ }^{4}$, Ruksana Najeeb ${ }^{5}$

${ }^{1}$ Lecturer, Department of Anesthesiology \& Critical Care, GMC, Srinagar.

${ }^{2}$ Senior Resident, Department of Anesthesiology \& Critical Care, GMC, Srinagar.

${ }^{3}$ Senior Resident, Department of Anesthesiology \& Critical Care, GMC, Srinagar.

${ }^{4}$ Senior Resident, Department of Anesthesiology \& Critical Care, GMC, Srinagar.

5 Professor, Department of Anesthesiology \& Critical Care, GMC, Srinagar.

\begin{tabular}{l}
\hline ABSTRACT \\
BACKGROUND \\
Obtaining adequate hemostasis is of utmost importance during surgery to improve the surgical field. \\
AIMS AND OBJECTIVES \\
The objective of this study is to determine the hemodynamic and haemostatic effects of same concentration of epinephrine with \\
or without local anesthetic used during the functional endoscopic sinus surgery.
\end{tabular}

\section{MATERIAL METHODS}

In prospective, randomized study was undertaken on sixty healthy patients. Group A received 8-10ml of epinephrine 1:200,000 with Lidocaine and Group B received 8-10ml of epinephrine 1:200,000 with normal saline.

\section{RESULTS}

In our study we found a statistically significant increase in SBP, DBP, MAP, HR from baseline value in group B with the value reaching a peak at around $5 \mathrm{~min}$ and then the parameters start normalizing towards baseline over several minutes. Whereas in case of group A patients, there was no significant changes in baseline values excepting a mild decrease in all parameters including SBP, DBP, MAP and HR.

\section{CONCLUSIONS}

The quality of surgical field was comparable in both groups without any significant differences. Addition of lignocaine to the epinephrine attenuates the cardiovascular side effects of epinephrine without affecting the visualization of the surgical field.

\section{KEYWORDS}

Hemodynamic Changes, Epinephrine, Lignocaine.

HOW TO CITE THIS ARTICLE: Geelani S, Bhat KA, Rather MA, et al. "Hemodynamic changes after epinephrine (1:200000) infiltration with or without lignocaine in ENT surgeries." Journal of Evolution of Medical and Dental Sciences 2015; Vol. 4, Issue 105, December 31; Page: 17005-17008, DOI: 10.14260/jemds/2015/2571

\section{INTRODUCTION}

The main aim of functional endoscopic sinus surgery is to clear air cells of disease and improve ventilation of the paranasal sinuses, thereby reducing the frequency and severity of infection.(1-2) The major limiting factors for endoscopic approaches to paranasal sinuses and the skull base are its complex anatomy and the high vascularity. Often, a slight haemorrhage is sufficient to dramatically reduce visibility creating a poor surgical field.(1-2) Thus, obtaining adequate haemostasis is of outmost importance during surgery to improve surgical field and prevent complications. Vasoconstriction is typically achieved by a combination of topical application and local infiltration of anaesthetic containing epinephrine. $(3,4,5)$ Topical vasoconstriction can be achieved by local application of epinephrine, oxymetazoline hydrochloride. $(3,6)$ Most otolaryngologists also use adequate submucosal infiltration of local anaesthetic containing epinephrine to further obtain haemostasis and reduce postoperative pain. $(7,8)$

Financial or Other, Competing Interest: None.

Submission 22-12-2015, Peer Review 23-12-2015,

Acceptance 26-12-2015, Published 30-12-2015.

Corresponding Author:

Mushtaq Ahmad Rather,

Senior Resident,

Department of Anesthesiology \& Critical Care,

GMC, Srinagar-190006.

E-mail: mushtaqahmad767@gmail.com

DOI:10.14260/jemds/2015/2571
Although epinephrine during functional endoscopic surgery provides excellent haemostasis, it can also be coupled with potential adverse effects such as hypertension, hypotension, tachycardia arrhythmias. Furthermore, these adverse effects may cause more serious complications in susceptible. $(9,10)$ In our presence study we had designed a randomized controlled trail assessing the hemodynamic and haemostatic effects of 1:200000 epinephrine with or without lignocaine during Functional Endoscopic Sinus Surgery (FESS).

After obtaining approval from hospital ethical committee the present study was undertaken in Government SMHS (Which is one of the associated hospitals of Government Medical College, Srinagar). This is a prospective, randomized study undertaken in the patients with age group between, 1140 years belonging to physical status ASA I.

\section{The criteria for exclusion from the study are:}

1. The patients younger than 11 years and older than 40 years.

2. Patients with bleeding disorders.

3. Patients with coronary artery disease.

4. Patients on antihypertensive.

5. Patients with ASA class $>$ I.

Patients selected for surgery were among those who stand admitted in ENT ward of the hospital. Pre-anaesthetic evaluation was done at least 24 hours prior to surgery. A 
history including previous anaesthetic exposure, medication and allergy to any drug was inquired about.

General physical examination and systematic examination including cardiovascular system, respiratory system and central nervous system was performed. Airway assessment was also done to predict any difficult intubation. All the investigations viz. CBC, BT, CT, LFT, KFT, CXR and ECG was checked. All the patients were weighed. The patients were advised to remain fasting overnight prior to surgery. On the day of surgery in operating room IV line was secured and RL started. The multichannel monitor was attached to the patient and baseline vitals viz. HR, NIBP, SP02 and ECG were recorded. Monitoring was continued intra-operatively.

\section{Study Groups}

This study was conducted in 60 patients who were distributed in two groups by systematic random sampling. Group A received $8-10 \mathrm{ml}$ of epinephrine 1:200,000 with lignocaine and Group B received $8-10 \mathrm{ml}$ of epinephrine 1:200,000 with normal saline. Each patient was induced with Propofol 1\%, 2$2.5 \mathrm{mg} / \mathrm{kg}$ body weight and muscle relaxation was achieved with Atracurium $0.5 \mathrm{mg} / \mathrm{kg}$ body weight for endotracheal intubation and surgical procedure. Anaesthesia was maintained with $\mathrm{N} 20+02+$ isoflurane $0.6 \%-1 \%$, with Etco2 between $32-42 \mathrm{mmHg}$.

\section{INTRAOPERATIVELY}

Intra-operatively data of the following patient parameters was collected during procedure using Datex-Ohmeda monitor: HR, ECG for arrhythmias, Systolic Blood Pressure, Diastolic Blood Pressure (SBP and DBP respectively), and Mean Arterial Pressure (MAP) measured from Blood Pressure (BP) cuff. These parameters were monitored throughout the procedure and were repeated 1 minute intervals for first 7 minutes. Two groups of patients were analysed: Group A received $8-10 \mathrm{ml}$ of epinephrine 1:200,000 with lignocaine and Group B received $8-10 \mathrm{ml}$ of epinephrine 1:200,000 with normal saline. There were no significant differences between the two groups with regard to age, sex, weight, ASA status and baseline SBP, DBP, MAP and HR. HR, SBP, DBP and MAP were recorded at $1 \mathrm{~min}$ interval for 7 minutes and the mean values were expressed as mean \pm SD. Intraoperatively quality of surgical field will be assessed using the following scale of Fromm and Boezaart.

\section{QUALITY OF SURGICAL FIELD}

\begin{tabular}{|c|l|}
\hline GRADE & \multicolumn{1}{c|}{ ASSESSMENT } \\
\hline 0 & Slight bleeding, cadaveric conditions. \\
\hline 1 & Slight bleeding, no suctioning required. \\
\hline 2 & Slight bleeding, occasional suctioning required. \\
\hline 3 & $\begin{array}{l}\text { Slight bleeding, frequent suctioning required. } \\
\text { Bleeding threatens Surgical field a few seconds } \\
\text { after suction is removed. }\end{array}$ \\
\hline 4 & $\begin{array}{l}\text { Moderate bleeding, frequent suctioning required, } \\
\text { bleeding that Threatens surgical field a few } \\
\text { seconds after suction is removed. }\end{array}$ \\
\hline 5 & $\begin{array}{l}\text { Severe bleeding, constant suctioning required. } \\
\text { Bleeding appears faster than can be removed by } \\
\text { the suction; surgical field severely threatened, } \\
\text { and surgery usually not possible. }\end{array}$ \\
\hline
\end{tabular}

\section{RESULTS}

There was no significant difference in the demographic profile of the patients in terms of Age, Weight and Gender as depicted in Table 1.

\begin{tabular}{|c|c|c|c|}
\hline & $\begin{array}{c}\text { Group A } \\
(\mathbf{n = 3 0 )} \\
\text { Mean } \pm \text { SD }\end{array}$ & $\begin{array}{c}\text { Group B (n=30) } \\
\text { Mean } \pm \text { SD }\end{array}$ & P value \\
\hline Age & $26.3 \pm 5.76$ & $25.6 \pm 6.32$ & 0.625 \\
\hline Weight & $50.4 \pm 5.68$ & $51.05 \pm 4.43$ & 0.270 \\
\hline Gender (M:F) & $18: 12$ & $16: 14$ & 0.672 \\
\hline \multicolumn{3}{|c|}{ Table 1: Demographic profile of the patients } \\
\hline
\end{tabular}

In our study we found a statistically significant increase in SBP, DBP, MAP and HR from baseline values in Group B with the values reaching a peak at around 5 minutes and then the parameters start normalizing towards baseline over several minutes. Whereas in case of Group A patients, there was no significant change in baseline values excepting a mild decrease in all parameters including SBP, DBP, MAP and HR. The quality of the surgical field was comparable in both the groups without any significant differences.

\begin{tabular}{|c|c|c|c|c|c|}
\hline \multirow{2}{*}{ Variable } & \multicolumn{2}{|c|}{$\begin{array}{c}\text { Group A } \\
(\mathbf{n = 3 0})\end{array}$} & \multicolumn{2}{c|}{$\begin{array}{c}\text { Group B } \\
\text { (n=30) }\end{array}$} & \multirow{2}{*}{$\begin{array}{c}\text { P- } \\
\text { value }\end{array}$} \\
\cline { 2 - 5 } & Mean & SD & Mean & SD & \\
\hline $\begin{array}{c}\text { Baseline } \\
\text { SBP }\end{array}$ & 121.5 & 4.86 & 120.0 & 6.58 & 0.323 \\
\hline $\begin{array}{c}\text { Baseline } \\
\text { DBP }\end{array}$ & 79.4 & 3.65 & 78.5 & 4.02 & 0.409 \\
\hline $\begin{array}{c}\text { Baseline } \\
\text { MAP }\end{array}$ & 93.4 & 3.20 & 92.4 & 3.62 & 0.240 \\
\hline Baseline HR & 75.2 & 4.23 & 75.5 & 3.50 & 0.811 \\
\hline \multicolumn{4}{|c|}{} & \multicolumn{4}{|c|}{ Table 2: Baseline Data } \\
\hline
\end{tabular}

Table 2: Baseline Data

The baseline vitals of the two groups were comparable without any significant differences.

\begin{tabular}{|c|c|c|}
\hline Time & $\begin{array}{c}\text { Group A } \\
\text { (Mean } \pm \text { SD) }\end{array}$ & $\begin{array}{c}\text { Group B } \\
\text { (Mean } \pm \text { SD) }\end{array}$ \\
\hline BL & $121.5 \pm 4.86$ & $120.0 \pm 6.58$ \\
\hline 1 Min & $122.0 \pm 3.45 \#$ & $126.0 \pm 5.75^{*}$ \\
\hline 2 Min & $123.7 \pm 3.42 \#$ & $131.1 \pm 4.10^{*}$ \\
\hline 3 Min & $123.1 \pm 2.73 \#$ & $137.77 \pm 5.54^{*}$ \\
\hline 4 Min & $122.4 \pm 4.42 \#$ & $142.2 \pm 3.12^{*}$ \\
\hline 5 Min & $121.0 \pm 3.04 \#$ & $148.73 \pm 3.29^{*}$ \\
\hline 6 Min & $120.4 \pm 3.79 \#$ & $146.47 \pm 3.27^{*}$ \\
\hline 7 Min & $121.4 \pm 4.55 \#$ & $142.1 \pm 4.23^{*}$ \\
\hline \multicolumn{2}{|c|}{ Table 3: Systolic Blood Pressure $(S B P)$} \\
\hline
\end{tabular}

*Statistically significant difference with baseline $(\mathrm{P}<0.05)$; \#Non-statistically significant difference with baseline $(\mathrm{P}>0.05)$.

Group B patients showed a statistically significant increase in SBP from baseline value over time as compared to Group A where there was no significant increase in SBP from baseline value.

\begin{tabular}{|c|c|c|}
\hline Time & $\begin{array}{c}\text { Group A } \\
\text { (Mean } \pm \text { SD) }\end{array}$ & $\begin{array}{c}\text { Group B } \\
\text { (Mean } \pm \text { SD) }\end{array}$ \\
\hline BL & $79.4 \pm 3.65$ & $78.5 \pm 4.02$ \\
\hline 1 Min & $80.3 \pm 3.10 \#$ & $82.73 \pm 3.38^{*}$ \\
\hline 2 Min & $81.0 \pm 2.19 \#$ & $84.4 \pm 4.25^{*}$ \\
\hline 3 Min & $80.9 \pm 3.36 \#$ & $89.37 \pm 3.12^{*}$ \\
\hline 4 Min & $82.2 \pm 5.87 \#$ & $93.03 \pm 5.28^{*}$ \\
\hline 5 Min & $80.7 \pm 3.97 \#$ & $96.97 \pm 2.93^{*}$ \\
\hline 6 Min & $77.91 \pm 4.09 \#$ & $91.27 \pm 2.80^{*}$ \\
\hline 7 Min & $76.91 \pm 4.70 \#$ & $90 \pm 3.52^{*}$ \\
\hline \multicolumn{2}{|c|}{ Table 4: Diastolic Blood Pressure (DBP) } \\
\hline
\end{tabular}

*Statistically significant difference with baseline $(\mathrm{P}<0.05)$; \# Non-statistically significant difference with baseline $(\mathrm{P}>0.05)$. 
Group B showing statistically significant increase in DBP from baseline as compared to Group A.

\begin{tabular}{|c|c|c|}
\hline Time & $\begin{array}{c}\text { Group A } \\
(\text { Mean } \pm \text { SD) }\end{array}$ & $\begin{array}{c}\text { Group B } \\
\text { (Mean } \pm \text { SD) }\end{array}$ \\
\hline BL & $93.4 \pm 3.20$ & $92.4 \pm 3.62$ \\
\hline 1 Min & $94.2 \pm 2.37 \#$ & $97.1 \pm 3.38^{*}$ \\
\hline 2 Min & $95.3 \pm 1.69 \#$ & $100 \pm 3.18^{*}$ \\
\hline 3 Min & $94.3 \pm 2.89 \#$ & $105.4 \pm 3.21^{*}$ \\
\hline 4 Min & $95.1 \pm 4.15 \#$ & $109.3 \pm 3.78^{*}$ \\
\hline 5 Min & $94.8 \pm 2.92 \#$ & $114.2 \pm 2.24^{*}$ \\
\hline 6 Min & $92.1 \pm 3.25 \#$ & $109.7 \pm 2.05^{*}$ \\
\hline 7 Min & $92.1 \pm 3.40 \#$ & $107.43 \pm 2.62^{*}$ \\
\hline \multicolumn{2}{|r|}{ Table 5: Mean Arterial Pressure (MAP) } \\
\hline
\end{tabular}

*Statistically significant difference with baseline $(\mathrm{P}<0.05)$; \# Non-statistically significant difference with baseline $(\mathrm{P}>0.05)$.

MAP also showed a significant increase from baseline value in Group B as compared to Group A.

\begin{tabular}{|c|c|c|}
\hline Time & $\begin{array}{c}\text { Group A } \\
\text { (Mean } \pm \text { SD) }\end{array}$ & $\begin{array}{c}\text { Group B } \\
\text { (Mean } \pm \text { SD) }\end{array}$ \\
\hline BL & $75.2 \pm 4.23$ & $75.5 \pm 3.50$ \\
\hline 1 Min & $75.6 \pm 3.52 \#$ & $82.8 \pm 3.48^{*}$ \\
\hline 2 Min & $73.7 \pm 5.14 \#$ & $88.5 \pm 3.91^{*}$ \\
\hline 3 Min & $77.2 \pm 4.83 \#$ & $93.7 \pm 2.69^{*}$ \\
\hline 4 Min & $75.6 \pm 4.38 \#$ & $98.2 \pm 3.71^{*}$ \\
\hline 5 Min & $75.7 \pm 4.00 \#$ & $108.2 \pm 3.38^{*}$ \\
\hline 6 Min & $74.4 \pm 3.23 \#$ & $103.8 \pm 3.45^{*}$ \\
\hline 7 Min & $74 \pm 5.08 \#$ & $98 \pm 2.59^{*}$ \\
\hline \multicolumn{3}{|c}{ Table 6: Heart Rate (HR) } \\
\hline
\end{tabular}

*Statistically significant difference with baseline $(\mathrm{P}<0.05)$; \#Non-statistically significant difference with baseline $(\mathrm{P}>0.05)$.

There was a significant increase in HR from the baseline in Group B as compared to Group A.

\begin{tabular}{|c|c|c|c|c|}
\hline Group & Mean & SD & P-Value & Significance \\
\hline Group A & 2.03 & 0.49 & \multirow{2}{*}{0.447} & NSSD \\
\hline Group B & 1.93 & 0.521 & & \\
\hline \multicolumn{6}{|c|}{ Table 7: Quality Of The Surgical Field (Hemostatis) } \\
\hline
\end{tabular}

NSSD $=$ non-statistically significant difference $(\mathrm{P}>0.05)$.

There was no significant difference in hemostatis and quality of the surgical field in the two groups.

\section{DISCUSSION}

Hemostatis including electric coagulation, compression, controlled hypotension etc., is one of the most important surgery techniques. FESS and mastoidectomy are commonly performed procedures in the Department of Otolaryngology and both require a good hemostatis to keep visualization clear and to decrease blood loss. Hemostatis can be achieved by vasoconstriction. $(11,12,13,14,15,16)$ Both topically applied and locally infiltrated vasoconstrictor agents reduces bleeding and improve visualization.(11-12) Adrenaline is a commonly used vasoconstrictor agent, infiltrated locally reduce bleeding and improve visualization.

However, it may lead to significant changes in heart rate and blood pressure. Earlier studies have shown that these changes depend on total dose of adrenaline, speed of absorption of adrenaline into the systemic circulation.(17) vascularity at the site of injection.(11) Lignocaine is generally added to the adrenaline solution to obviate these unfavourable cardiovascular side effects through its action on the myocardium and systemic vasculature. In addition, lignocaine also suppresses the highly nociceptive stimulus caused by the dissection of the subcutaneous tissue because of large amounts of solution used for infiltration. The increase in the baseline values seen in Group B (Adrenaline without Lignocaine) may be explained on the basis of vasoconstriction resulting from the effect of adrenaline on the alpha-1 receptors.

Decrease in the baseline values seen in Group A (Adrenaline with lignocaine), is probably as a result of potentiation of $\beta-2$ effects of adrenaline by lidocaine. At small plasma concentrations adrenaline exerts a predominant $\beta-2$ effect.(18) The myocardial depressant and vasodilatory effects of lignocaine seem to potentiate $\beta$ - 2 effects of adrenaline and cause hypotension. The $\beta-2$ effects of adrenaline seem to cause hypotension only in the presence of lignocaine, because a similar decrease in BP was not seen in Group B, which received only adrenaline.

Other studies also reported a decrease in baseline parameters when adrenaline is used with lignocaine. Hanuman and Umamaheswara reported more than 20\% decrease of MAP in $40 \%$ of the patients compared to the preinfiltration values.(13) Philips and his colleagues noted significant decrease in mean arterial pressure in $55 \%$ of the patients.(8) Yang and his colleagues found decrease in mean arterial pressure in $24 \%$ of patients when lignocaine was combined with adrenaline.

\section{SUMMARY AND CONCLUSION}

In patients undergoing ENT surgeries (FESS, Mastoidectomy etc.) local infiltration reduces bleeding and improves visualization of the surgical field but at the same time it causes cardiovascular side effects like tachycardia and hypertension, due to systemic absorption of the drug. Addition of lignocaine to the adrenaline attenuates the cardiovascular side effects of adrenaline without affecting the visualization of the surgical field.

\section{REFERENCES}

1. Stammberger H, Kopp W. Functional Endoscopic Sinus Surgery: The Masserklinger Technique. Philadelphia, PA BC Decker 1991.

2. Stammberger H, Posawetz W. Functional endoscopic sinus surgery: concepts, indications and result of the Messerklinger technique. Eur Arch Otorhinolaryngol 1990;247(2):63-76.

3. Hirshowitz B, Eliachar I. Effective haemostasis with local anaesthesia in nasal surgery. Br J Plast Surg 1972;25(3):335-341.

4. Lee WC, Kapur TR, Ramsden WN. Local and regional anaesthesia for functional endoscopic sinus surgery. Ann Otol Rhinol Laryngol 1997;106(9):767-769.

5. McClymont LG, Crowther JA. Local anaesthetic with vasoconstrictor combinations in septal surgery. J Larryngol Otol 1988; 102(9):793-795.

6. Liao BS, Hilsinger RL Jr, Rasgon BM, et al. A preliminary study of cocaine absorption from the nasal mucosa. Laryngoscope 1999;109(1):98-102. 
7. Wormald PJ, Athanasiadis T, Rees G, et al. An evaluation of effect of pterygopalatine fossa injection with local anaesthetic and adrenaline in the control of nasal bleeding during endoscopic sinus surgery. Am J Rhinol 2005;19(3):288-292.

8. Vanniasegaram I. Prospective study of the use of vasoconstrictor and saline in septal surgery for infiltration. J laryngol Otol 1991;105(8):638-639.

9. Horrigan R, Weger EI, Wilson C. Epinephrine-induced arrhythmias during enflurane anaesthesia in man: a nonlinear dose-response relationship and dosedependent protection from lidocaine. Anesth Analg 1978;57(5):547-550.

10. Murthy HS, Rao GS. Cardiovascular responses to scalp infiltration with different concentrations of epinephrine with or without lidocaine during craniotomy. Anesth Analg 2001;92(6):1516-1519.

11. Stammberger H, Posawetz W. Functional endoscopic sinus surgery. Concepts, indications and result of the Messerklinger technique. Eur Arch Otorhinolaryngol 1990;247:63-76.

12. Lee WC, Kapur TR, Ramsden WN. Local and regional anaesthesia for functional endoscopic sinus surgery. Ann Otol Rhinol Laryngol 1997;106:767-769.
13. Sorensen WT, Wagner N, Aarup AT, et al. Beneficial effect of low-dose peritonsillar injection of lidocaine adrenaline before tonsillectomy. A placebo-controlled clinical trial. Auris Nasus Larynx 2003;30:159-162.

14. Kara CO, Kaftan A, Atalay H, et al. Cardiovascular safety of cocaine anaesthesia in the presence of adrenaline during septal surgery. J Otolaryngol 2001;30:145-148.

15. John G, Low JM, Tan PE, et al. Plasma catecholamine levels during functional endoscopic sinus surgery. Clin Otolaryngol 1995;20:213-215.

16. Dunlevy TM, O'Malley TP, Postma GN. Optimal concentration of epinephrine for vasoconstriction in neck surgery. Laryngoscope 1996;106:1412-1414.

17. Blackwell KE, Ross DA, Kapur P, et al. Propofol for maintenance of general anaesthesia: a technique to limit blood loss during endoscopic sinus surgery. Am J Otolaryngol 1993;14:262-266.

18. Homma Y, Ichinohe T, Kaneko Y. Oral mucosal blood flow, plasma epinephrine and haemodynamic responses after injection of lidocaine with epinephrine during midazolam sedation and isoflurane anaesthesia. $\mathrm{Br} \mathrm{J}$ Anaesth 1999;82:570-574. 